\title{
O LEMA "APRENDER A APRENDER" NO ENSINO DE LITERATURA: PRECISAS IMPLICAÇÕES NO PROCESSO DE FORMAÇÃO HUMANA
}

\section{Resumo}

Larissa Quachio Costa ${ }^{1}$

O trabalho que ora se apresenta presta-se a traçar algumas reflexões acerca da influência do lema "Aprender a aprender" no campo do ensino da Língua Portuguesa e, portanto, de Literatura, e suas implicações para o processo de desenvolvimento humano. $\mathrm{O}$ artigo defende o argumento de que tal influência é um dos aspectos característicos das concepções pósmodernas, cuja origem deve ser averiguada nas primeiras manifestações do processo de decadência ideológica da burguesia, no século XIX. Com base nos pressupostos da pedagogia histórico-crítica, também argumenta que as propostas de ensino pautadas nos princípios do pensamento pós-moderno preconizam a não socialização do saber objetivo e, assim, refletem os instrumentos ideológicos da classe dominante, cujo propósito é esvaziar a educação escolar destinada à maioria da população.

Palavras-chave: Decadência ideológica. Pensamento pós-moderno. Arte literária. Pedagogia histórico-crítica. Ensino de literatura.

\section{THE LEMA "LEARNING TO LEARN" IN LITERATURE TEACHING: PRECISE IMPLICATIONS IN THE PROCESS OF HUMAN TRAINING}

\begin{abstract}
The study proposed herewith lends itself to trace some reflections on the influence of the motto "Learning to learn skills" in the teaching of Portuguese and therefore literature, and its implications for human development. This paper expresses the argument that the such influence is one of the characteristic features of postmodern conceptions whose origin should be checked in the first few manifestations of the ideological process of decay of the bourgeoisie in the nineteenth century. Based on the assumptions of historical-critical pedagogy, it also brings the argument that the teaching proposals based on the principles of postmodern thought advocate the non-socialization of objective knowledge and thus reflect the ideological instruments of the ruling class, whose purpose is to empty school education aimed at majority of the population.
\end{abstract}

Keywords: Ideological decay. Postmodern thought. Literary art. Historical-critical pedagogy. Literature teaching. 


\section{Revista HIIS'TEIDBR On-lime}

\section{INTRODUÇÃO}

Procuramos expor aqui os aspectos gerais da análise de Lukács sobre as consequências das Revoluções de 1848 para a sociedade, ou seja, o declínio da burguesia como classe revolucionária e o consequente perecimento de sua ideologia - a "decadência ideológica". Estabelecemos uma relação entre as primeiras manifestações desse processo em meados do século XIX e a chamada pós-modernidade. Defendemos que, no âmbito educacional, essa relação se encontra no movimento das pedagogias hegemônicas contemporâneas articuladas ao lema "aprender a aprender", cujas bases se encontram no movimento da Escola Nova. A partir dessa breve análise sobre origem do pensamento pósmoderno e suas implicações para a sociedade contemporânea e considerando que a escola não pode ser compreendida deslocada da sua relação com a sociedade, objetivamos refletir como a produção intelectual do período da decadência e, agora, influenciada fortemente pela ideologia do pensamento pós-moderno, interfere ainda na educação escolar e, por conseguinte, no ensino de Língua Portuguesa. Nossos argumentos se pautam na tese segundo a qual o ensino assistemático da língua não contribui efetivamente para o desenvolvimento integral do ser humano.

\section{AS REVOLUÇÕES DE 1848 E A REAÇÃO BURGUESA}

A Revolução, antes de tudo, conquistará para cada indivíduo, em duras lutas, o direito à poesia, e não somente ao pão. (TROTSKY, 2007, p. 201).

Paris, 24 de fevereiro de 1848, pela manhã, está em plena revolução. Louis-Philippe abdica do trono francês em favor de seu neto, o Conde de Paris. Os revoltosos invadem a Câmara dos Deputados a fim de evitar que a regência seja confiada à duquesa de Orléans. Ao anoitecer, um governo provisório é estabelecido. A monarquia francesa havia sido derrubada por uma insurreição e a república proclamada.

Segundo Eric J. Hobsbawm (2015, p. 43-46), historiador marxista, os eventos de 1848 ficaram conhecidos como "A primavera dos povos" e, como a primavera, não durou, pois as revoluções foram vitoriosas e derrotadas rapidamente. "[...] 1848 aparece como a revolução da moderna história da Europa que combinou a maior promessa, a maior extensão, o maior sucesso inicial imediato e o mais rápido e retumbante fracasso".

Em fevereiro de 1848, o proletariado, movido por suas condições materiais de vida, almejava a uma mudança radical das relações sociais e, assim, age na direção de sua potencialidade mais ampla; mas posiciona-se equivocadamente na conjuntura que se desenvolve porque desconhece os fundamentos das contradições entre capital e trabalho. "A revolução de fevereiro suprimira a monarquia constitucional efetivamente e a dominação da burguesia na ideia”. (MARX, 2010, p. 412, grifo do autor).

Refletindo sobre as estratégias da luta operária de 1848, Karl Marx (1986, p. 71, grifo do autor) adverte que "[...] o proletariado de Paris ainda não era capaz de sair dos limites da república burguesa, a não ser nas suas ilusões, na sua imaginação; como agia sempre e por toda parte a serviço da república burguesa". Destronada a monarquia, o operariado presumia haver derrubado a dominação do capital, pois a forma monárquica representava-lhe a 


\title{
Revista HIIST'TEIDBR On-line
}

Artigo

doi: $10.20396 /$ rho.v17i3.8645880

dominação de classe e a república a supressão da dominação burguesa.

A ilusão a que Marx se refere é a crença na eliminação das classes como resultado da mudança na forma de estado; pois a república, instituída após a insurreição de fevereiro, revelar-se-á como outra forma de domínio de classe. "A continuidade das classes e da dominação burguesa evidencia-se logo que vêm ao primeiro plano problemas da sociedade civil: a crise industrial que vinha se arrastando, com a consequente piora nas condições de vida". (COTRIM, 2010, p. 33).

Conforme expõe Marx (2010, p. 154), a fraternidade entre as classes antagônicas, ideal conclamado em fevereiro, "[...] durou enquanto o interesse da burguesia esteve irmandado ao interesse do proletariado": a instauração da república. Assim, as ilusões dos insurgentes se desvaneceram. A instituição da república dissipou as ilusões nutridas pelos trabalhadores até então, aclarou as posições das classes e viabilizou o rebentamento de seu antagonismo. Segundo Marx (2010, p. 154), o proletariado conheceu a expressão verdadeira e prosaica da Fraternité: "[...] a guerra civil em sua figura mais terrível, a guerra do trabalho contra o capital".

Para Marx (2010, p. 150-153), o aniquilamento das mistificações e ilusões da insurreição de fevereiro garantiu "[...] o triunfo momentâneo da força bruta" e possibilitou o avanço em direção "[...] à maior revolução que já ocorreu, à revolução do proletariado contra a burguesia [...]", ao confronto decisive das revoluções de 1848 - o de junho, em Paris. Sobre esse evento, György Lukács (2011b, p. 211), filósofo húngaro, diz:

\begin{abstract}
A batalha do proletariado parisiense em junho de 1848 foi uma reviravolta na história em escala internacional. [...] é apenas aí que se deflagra pela primeira vez uma batalha decisiva entre proletariado e burguesia com a violência das armas; o proletariado pisa pela primeira vez no palco histórico-mundial como uma massa armada, decidida a travar a luta decisiva; nesse momento, a burguesia luta pela primeira vez pela continuação de seu domínio econômico e político.
\end{abstract}

Foi nas jornadas de junho - de 23 a 26 de junho de 1848 - que o proletariado se afirmou como classe revolucionária independente da burguesia. Os trabalhadores reivindicavam a continuidade, no plano social, dos avanços que a burguesia havia alcançado, no plano jurídico, com a Revolução Francesa, isto é, a igualdade de fato, a garantia de acesso à propriedade. $\mathrm{O}$ proletariado exigia "[...] não só pão e emprego, mas também uma sociedade e um novo Estado". (HOBSBAWM, 1979, p. 329).

Conforme afirma Marx (2010), a revolução de junho atentou contra a ordem burguesa, a dominação de classe e a escravidão do trabalhador; e a burguesia, balizada pela posição do operariado e consciente do perigo que corria a ordem do capital, respondeu ao levante com metralhas e barricadas. A reação burguesa, procurando perpetuar o status quo, arremeteu contra a massa de trabalhadores e miseráveis. As revoluções de 1848 "[...] deveriam ter sido 'revoluções burguesas', mas a burguesia fugiu delas". Os trabalhadores "[...] lutaram e morreram bravamente" (HOBSBAWM, 2015, p. 51-65).

Segundo Marx (2010, p. 153, grifo do autor), “[...] os trabalhadores parisienses foram esmagados pela superioridade numérica, não foram abatidos por ela". O filósofo conclui que os revolucionários foram batidos, mas seus opositores foram vencidos; pois, apesar do massacre sofrido, alcançaram a vitória com o desanuviamento das contradições, com a 


\section{Revista HIIST'TEIDBR On-line}

demarcação nítida das relações sociais e das posições das classes, enfim, com a dissipação das ilusões de fevereiro. Para o filósofo, "[...] o fruto principal do movimento revolucionário de 1848 não foi o que os povos ganharam, mas sim o que perderam - a perda de suas ilusões" (2010, p. 453).

Diante do exposto, podemos dizer que as jornadas de 1848, sobretudo as de junho, trouxeram à consciência social a oposição entre capital e trabalho, deslocaram para o nível das experiências imediatas o antagonismo entre burguesia e proletariado, enfim, desnudaram "a cabeça do monstro": a dominação da burguesia e a escravidão dos trabalhadores. (MARX, 2010, p. 154).

Como atesta Hobsbawn (2015), a burguesia, perante a ameaça à propriedade privada, percebeu que preferia a ordem à oportunidade de pôr em prática o projeto teórico que havia proferido durante o Século das Luzes. "Os partidos burgueses traíram [...] os grandes interesses - ligados ao povo - da revolução democrático-burguesa [...], traíram os interesses da democracia" em favor das necessidades de expansão e acumulação do capital e da sua posição no âmbito do controle político. (LUKÁCS, 2010, p. 52).

De acordo com Lukács (2010, p. 51), as insurreições de 1848 se configuram como o marco do declínio da burguesia como classe revolucionária e do consequente perecimento de sua ideologia. O pensador húngaro afirma que quando a burguesia " [...] já domina o poder político e a luta de classes entre ela e o proletariado se coloca no centro do cenário histórico [...]" tem início a sua decadência ideológica, tendência de vulgarização e capitulação da filosofia burguesa.

\section{DECADÊNCIA IDEOLÓGICA: VULGARIZAÇÃO E CAPITULAÇÃO DA FILOSOFIA BURGUESA}

Segundo Carlos Nelson Coutinho (1972), intelectual brasileiro adepto dos ensinamentos de Lukács, podemos estremar duas fases precípuas na história da filosofia burguesa: a primeira que corresponde ao momento em que a burguesia, ao se opor à resistência absolutista-feudal, defende de modo objetivo os interesses da totalidade do povo e, portanto, o progresso social; e a segunda que se refere à revolução europeia de 1848, quando o proletariado desponta na história como classe autônoma e capaz de dissolver as novas contradições provocadas pelo próprio capitalismo triunfante e a burguesia, consequentemente, torna-se conservadora e trai a causa do progresso social.

Como afirma Coutinho $(1972,2010)$, durante a primeira fase, os representantes ideológicos burgueses julgam a realidade como um todo racional e consideram possível para a "Razão humana" seu conhecimento e domínio; mas, no decurso da segunda, tem início a decadência ideológica da burguesia, pois esta passa a se interessar pelo perpetuamento do existente, a inviabilizar gradativamente a apreensão objetiva da realidade, a encarar a "Razão" com um ceticismo crescente, a renegá-la como instrumento do conhecimento e a limitá-la a âmbitos menos significativos da realidade. "A razão [...] deixa de ser a imagem da legalidade objetiva da totalidade real [...]”. (COUTINHO, 2010, p. 51).

Essa conversão da filosofia burguesia e seus desdobramentos serão aclarados, portanto, a partir das revoluções de 1830 e mais ainda depois das de 1848. Essa crise 
espiritual burguesa e a sua degeneração como classe revolucionária após 1848 correspondem ao conceito de decadência ideológica, tendência do pensamento contemporâneo denunciada por Karl Marx e Friedrich Engels e analisada por Lukács.

Segundo Lukács (2010, p. 51), a decadência principia-se quando a burguesia domina o poder político e a luta de classe entre ela e o proletariado se coloca no centro do cenário histórico. Podemos dizer, portanto, que o pensamento social pós-1848, com poucas exceções, foi se adequando às circunstâncias históricas do modo de produção capitalista e, dessa forma, a vocação apologética de negação das contradições da vida real surge como imperativo da burguesia para assegurar seu poder material e espiritual.

Podemos afirmar que a burguesia, cerceada pelo conflito de classes, passa a ter necessidade de assegurar a ordem social por meio de justificações teóricas dos problemas decorrentes do desenvolvimento capitalista, ou seja, suas expressões ideológicas nesse momento buscam não desvendar, mas encobrir as contradições que seu domínio de classe acarreta, visando a reprodução do status quo.

É importante enfatizarmos que, como atesta Lukács (2010, p. 61), as questões fundamentais da decadência ideológica da burguesia, como aquelas do período clássico de sua ideologia, configuram-se como respostas aos problemas suscitados pelo desenvolvimento social do capitalismo. O filósofo húngaro argumenta:

\begin{abstract}
A diferença reside "apenas" em que os ideólogos anteriores forneceram uma resposta sincera e científica, mesmo se incomplete e contraditória, ao passo que a decadência foge covardemente da expressão da realidade e mascara a fuga mediante o recurso ao "espírito científico objetivo" ou a ornamentos românticos. Em ambos os casos, é essencialmente acrítica, não vai além da superfície dos fenômenos, permanece no imediatismo e cata ao mesmo tempo migalhas contraditórias de pensamento, unidas pelo laço do ecletismo.
\end{abstract}

Dessa forma, podemos afirmar que o pensamento da decadência favorece ideologicamente os insteresses da burguesia por se restringir à captação imediata da realidade. Lukács (1966b, p. 329) trata da "imediaticidade":

\footnotetext{
O termo imediaticidade não designa [...] uma atitude psicológica cujo oposto, ou cujo desenvolvimento, seria a consciência; designa, ao contrário, um certo nível de recepção do conteúdo do mundo exterior, independentemente da circunstância de que essa recepção ocorra com maior ou menor consciência. Lembro os exemplos econômicos que adotei [...]. Se alguém enxerga a essência do capitalismo na circulação do dinheiro, o nível de suas concepções é imediato, memso que, depois de dez anos de grandes esforços intelectuais, exponha-as em um douto volume de duas mil páginas. Ao contrário, se um operário captou instintivamente o problema da mais-valia, ultrapassou já essa imediaticidade dos fatos econômicos.
}

No processo de consolidação do poder burguês, portanto, o saber, cujo objetivo era desvendar as reais contradições da sociedade, começa a ser substituído pelo saber compromissado com as instituições oficiais do sistema capitalista. De acordo com Lukács (2010, p. 54), nesse momento, o impulso dos apologetas a falsificar a realidade leva a doutrina científica a se afastar da vida que deveria refletir. "Esse afastamento da vida, próprio da pseudociência eclética, transforma cada vez mais as afirmações da ciência em 


\title{
Revista HIIS'TEIDBR On-lime
}

Artigo

doi: $10.20396 /$ rho.v17i3.8645880

frases vazias".

A razão, "[...] conceito de que o real é racional e pode ser objetivamente conhecido", converte-se em ferramenta ideológica de justificação do existente - a realidade alienada do capitalismo - e a intuição - que se baseia na mera vivência subjetiva imediata - torna-se o único instrumento válido do conhecimento: “[...] o irracional subjetivo e arbitrário destrona a razão objetiva”. (COUTINHO, 1967, p. 10-12).

Segundo Coutinho $(1967 ; 2010)$, o fato de a razão servir a objetivos globais irracionais, em vez de elaborar as categorias a partir de sua essência econômica, fornece ao indivíduo - desligado do processo histórico global devido à intensa divisão do trabalho uma visão irracionalizada da realidade, o que lhe priva de condições para compreender as razões reais do caos aparente. "[...] o miserável racionalismo da decadência preocupa-se [...] em estabelecer 'limites' para o conhecimento [...]”. (COUTINHO, 2010, p. 51).

O irracionalismo diz respeito tanto ao subjetivismo exacerbado - "a afirmação da 'experiência vivida' como único método de conhecimento, a concepção da subjetividade como única fonte de valores morais autênticos [...]" - quanto ao objetivismo positivista e metafísico - "a teoria de que certos aspectos da vida humana são eternos e ontológicos, a sensação de impotência em face da realidade, o 'pessimismo cósmico' fundado no fatalismo [...]”. (COUTINHO, 1967, p. 13). Sobre o irracionalismo, Lukács diz:

\begin{abstract}
A falta de sentido da vida significa, antes de mais nada, a liberação do indivíduo de todos os deveres sociais, de toda responsabilidade em face do desenvolvimento progressista da humanidade [...]. O abismo do nada, o fundo sombrio da falta de sentido da existência, é como um condimento picante que dá sabor e encanto ao gôzo da vida [...]. Êste irracionalismo alcança a meta central a que se propõe [...] e nada mais é do que oferecer uma apologia indireta da ordem social do capitalismo. (LUKÁCS, 1959, p. 201, tradução nossa)
\end{abstract}

Essa conversão da burguesia como classe, conforme assevera Coutinho (2010), transforma o pensamento burguês, por meio de seus representantes ideológicos, em fonte do aumento da alienação humana e essa alienação se faz necessária porque tem a finalidade de reduzir as possibilidades de ações revolucionárias. Se o conhecimento objetivo explicita e fundamenta a necessidade de superação das profundas contradições geradas pela sociedade capitalista, os cientistas e intelectuais alinhados à ideologia burguesa afastam-se cada vez mais do compromisso com a busca da verdade e transformam-se, em graus diversos, em apologistas do capital.

A burguesia, ao se defender do proletariado ascendente, a fim de evitar suas ameaças de um processo revolucionário, renuncia, pois, aos seus ideais emancipatórios, passa a buscar a conservação do regime explorador que estabeleceu, torna-se conservadora, desinteressa-se pela verdade porque esta, conforme afirma Dermeval Saviani (2008a, p. 100), é revolucionária, colide com seus interesses. "[...] a verdade histórica evidencia a necessidade das transformações [...]".

Enfim, a decadência ideológica e cultural da burguesia, logo, caracteriza-se pela contradição entre o avanço material e uma espécie de estagnação cultural, cujas consequências se desdobraram em diversos níveis da atividade humana, inclusive na ciência, na filosofia e na arte. Além disso, como afirma José Paulo Netto (2010, p. 255), a decadência 


\section{Revista HIIST'TEIDBR On-line}

ideológica não possui fronteiras nacionais e abarca o conjunto do mundo ocidental, o que nos permite refletir acerca da possibilidade de haver aí o germe do ambiente ideológico do capitalismo contemporâneo - o universo neoliberal e pós-moderno -; pois, por meio deste, a classe dominante consegue, ainda, controlar a produção do conhecimento e quanto ele possa e deva ser difundido à grande parte da população, a fim de mantê-la em níveis de consciência que possibilitem sua manipulação ideológica.

\section{PENSAMENTO PÓS-MODERNO: CONSEQUÊNCIA DA DECADÊNCIA IDEOLÓGICA}

Como afirma José Paulo Netto (2010, p. 255), a decadência ideológica não possui fronteiras nacionais e abarca o conjunto do mundo ocidental, o que nos permite refletir acerca da possibilidade de haver aí o germe do ambiente ideológico do capitalismo contemporâneo - o universo neoliberal e pós-moderno -; pois os tempos atuais dão-nos evidências de que a origem das características do pensamento pós-moderno deve ser averiguada nas primeiras manifestações do processo de decadência ideológica da burguesia. Segundo José Luis Derisso (2010), o pensamento pós-moderno é consequência do processo que Lukács (2010) chamou de decadência ideológica, isto é, a forma de pensamento predominante no presente estágio da sociedade burguesa carrega os traços do irracionalismo característico da decadência ideológica do pensamento burguês.

Newton Duarte (2004, p. 219-221), em seu artigo intitulado "A rendição pósmoderna à individualidade alienada e a perspectiva marxista da individualidade livre e universal", afirma que o pós-modernismo leva às últimas consequências as tendências irracionalistas já presentes no pensamento burguês desde o século XIX e que se acentuaram fortemente durante o século XX. De acordo com Duarte, o pós-modernismo corresponde a várias correntes do pensamento, cuja atitude é cética em relação à razão, à ciência, ao marxismo e à possibilidade de o capitalismo ser superado por uma sociedade que lhe seja superior.

Conforma atesta Duarte (2004), o pós-modernismo nega o conceito de alienação e considera que não há uma perspectiva a partir da qual possa ser realizada a crítica à sociedade alienada, pois tal crítica requer uma metanarrativa e o distanciamento em relação ao contexto social que esteja sendo criticado. "O pós-modernismo rejeita tanto as metanarrativas como a possibilidade de o sujeito se distanciar da realidade da qual ele é parte" (DUARTE, 2004, p. 220).

Dessa forma, Duarte conclui que (2004, p. 227), “[...] pela perspectiva pós-moderna, não há parâmetros para diferenciar o que é humanizante do que é alienante, pois sem uma teoria do processo histórico de humanização e sem uma teoria da alienação não é possível realizar a crítica a qualquer tipo de fetichismo".

Podemos afirmar, então, que o pensamento pós-moderno postula a impossibilidade ou a indeterminação do conhecimento, a inacessibilidade da realidade objetiva. De acordo com Chauí (1993, p. 22-23), tal ideário nega a possibilidade de a razão propor uma continuidade temporal e, assim, captar o sentido imanente da história; nega a viabilidade de a razão apreender o núcleo da universalidade no real e, assim, favorece o espaço e o tempo 


\section{Revista HIIST'TEIDBR On-line}

Artigo

doi: $10.20396 /$ rho.v17i3.8645880

fragmentados, a descontinuidade, o privilégio do universo privado e íntimo em detrimento do público, o efêmero, o descartável.

Enfim, conforme afirma Duarte (2006), relativismo, irracionalismo e fragmentação são aspectos característicos das concepções pós-modernas, cuja origem deve ser buscada na realidade do capitalismo contemporâneo, na ideologia do modelo neoliberal. Para Duarte, assim, há uma indesatável relação entre as variadas formas de manifestação do pensamento pós-moderno e a realidade social do capitalismo contemporâneo, do qual o pensamento neoliberal apresenta-se como explícito defensor.

O pós-modernismo e o neoliberalismo, portanto, fundamentam-se na premissa do desprezo à história dos homens e do trabalho, gerando afastamento e esvaziamento da vida objetiva, legitimando a vida cotidiana alienante, falseando a realidade na e pela valorização demasiada da subjetividade, do imediatismo, do particularismo e do localismo.

Diante da exposição das características da decadência ideológica do pensamento burguês, no século XIX, e dos aspectos das concepções pós-modernas, podemos afirmar que se Lukács estivesse vivo diria que a decadência perdura; pois, assim como a tendência de vulgarização e capitulação da filosofia burguesa, o pensamento pós-moderno contemporâneo também afirma a impotência do ser humano, ou seja, a sua incapacidade de conhecer a realidade e, consequentemente, a incapacidade humana de transformar a sociedade.

Dessas análises sobre uma breve caracterização da origem do pensamento pósmoderno e suas implicações para a sociedade contemporânea e partindo do pressuposto de que a escola não pode ser entendida deslocada da sua relação com a sociedade, ressaltamos aqui o fato de o relativismo ser forte componente do pensamento pós-moderno, com sérias consequências para os campos da educação.

A escola situa-se predominantemente no campo da difusão do conhecimento, no qual refletem as contradições que se agudizam no campo da produção e da sistematização do conhecimento na época da decadência ideológica e, nas últimas décadas, na sociedade considerada pós-moderna. Dessa forma, precisamos refletir como a produção intelectual do período da decadência e, agora, influenciada fortemente pela ideologia do pensamento pósmoderno, interfere na educação escolar.

Perante o exposto, podemos afirmar que o pensamento pós-moderno é consequência do processo que Lukács chamou de decadência ideológica, pois ambos expressam o desinteresse da classe burguesa pela verdade; e realizada a relação entre o pensamento pósmoderno e a decadência ideológica, podemos compreender o porquê de a literatura e, mais especificamente, o ensino de literatura, no Brasil, sofrer efeitos nefastos oriundos de sua subordinação aos interesses do capitalismo tanto do ponto de vista econômico quanto do ideológico.

\section{O LEMA “APRENDER A APRENDER": EXPRESSÃO DA DECADÊNCIA IDEOLÓGICA}

Em relação ao plano pedagógico, Duarte (2009) considera a emergência e ampla difusão da pedagogia escolanovista e todas as suas variantes - entre estas o lema "Aprender 


\section{Revista HIISTEYIDIR On-line}

a aprender" -, ao longo do século XX, a expressão, no campo educacional, do fenômeno mais amplo caracterizado por Lukács: a decadência ideológica do pensamento burguês após as revoluções de 1848.

Na década de 1990, devido à ascensão de governos ditos neoliberais, empreendemse, no país, reformas educacionais conforme diretrizes de organismos internacionais e com isso há a atualização do lema "Aprender a aprender"2, que já havia sido pregoado pelo movimento escolanovista e alcançou nova vigência na retórica de diversas concepções educacionais contemporâneas, sobretudo no Construtivismo.

Sobre o movimento construtivista, Duarte (2006, p. 30) afirma que está vinculado ao processo de mundialização do capital e ao processo de difusão tanto do modelo econômico, político e ideológico neoliberal quanto de um de seus correlatos, no plano teórico: o pósmodernismo.

Tal movimento ganha força justamente no interior do aguçamento do processo de mundialização do capital e de difusão, na América Latina, do modelo econômico, político e ideológico neoliberal e também de seus correspondentes no plano teórico, o pós-modernismo e o pós-estruturalismo.

Esse esvaziamento do trabalho educativo escolar, essa negação da tarefa da escola de possibilitar o acesso à verdade é a expressão, para Duarte (2006, p. 09), no âmbito educacional, da atual crise cultural gerada por um dos pilares centrais do universo ideológico da sociedade capitalista contemporânea, o ideário pós-moderno. $\mathrm{O}$ autor afirma que o lema "Aprender a aprender" é um dos instrumentos ideológicos da classe dominante, cujo propósito é esvaziar a educação escolar destinada à maioria da população.

Duarte (2006) discute também os princípios do lema “Aprender a aprender" e atesta que o eixo caracterizador deste se encontra na desvalorização da transmissão do saber objetivo, na diluição do papel da escola em transmitir esse saber, portanto, na dissolução da função da escola de proporcionar ao educando o acesso à verdade. Esse lema critica o caráter objetivo do conhecimento e, em contrapartida, supervaloriza a espontaneidade, o lúdico, o prazer, os aspectos emocionais em detrimento dos racionais.

O autor afirma ainda que esse lema desempenha uma relevante função na adequação do discurso pedagógico contemporâneo às necessidades do processo de mundialização do capitalismo, devido à sua interna vinculação à categoria de adaptação que ocupa posição de destaque tanto no discurso político-econômico neoliberal como nas teorias epistemológicas, psicológicas e pedagógicas de cunho construtivista.

[...] o lema "aprender a aprender" [...] preconiza que à escola não caberia a tarefa de transmitir o saber objetivo, mas sim a de preparar os indivíduos para aprenderem aquilo que deles for exigido pelo processo de sua adaptação às alienadas e alienantes relações sociais que presidem o capitalismo contemporâneo. A essência do lema "aprender a aprender" é exatamente o esvaziamento do trabalho educativo escolar, transformando-o num processo sem conteúdo. Em última instância o lema "aprender a aprender" é a expressão, no terreno educacional, da crise cultural da sociedade atual. (DUARTE, 2006, p. 9).

O “aprender a aprender”, portanto, sintetiza uma concepção educacional direcionada para a formação da capacidade adaptativa dos indivíduos, pois, conforme assevera Duarte 


\section{Revista HIIST'TEIDBR On-line}

(2006), quando educadores e psicólogos apresentam o "aprender a aprender" como síntese de uma educação destinada a formar indivíduos criativos, é importante atentar para um detalhe essencial: essa criatividade não se trata da busca de transformações radicais na realidade social, da busca de superação radical da sociedade capitalista, mas sim da criatividade em termos de capacidade de encontrar novas formas de ação que possibilitem melhor adaptação aos ditames do processo de produção e reprodução do capital.

O lema “Aprender a aprender", para Duarte (2006, p. 42), é um dos instrumentos ideológicos da classe dominante cujo propósito é esvaziar a educação escolar destinada à maioria da população enquanto são buscadas formas de aprimoramento da educação das elites: "[...] a adesão a esse lema implica necessariamente a adesão a todo um ideário educacional afinado com a lógica da sociedade capitalista contemporânea".

Tanto o lema "Aprender a aprender" quanto o ideário pós-moderno contribuem para o "esvaziamento completo" (MARX apud DUARTE, 2006, p. 54) do ser humano no capitalismo na medida em que não visam à formação plena do indivíduo e sim à sua "[...] adaptação incessante aos ventos do mercado" (DUARTE, 2006, p. 54), à sua permanência na profunda alienação que caracteriza a vida cotidiana na sociedade capitalista, ao domínio de suas consciências tornando-lhes seres interiormente vazios que só conseguem pensar e agir conforme os estereótipos ditados pelo capital.

Diante do exposto, podemos afirmar que o lema "Aprender a aprender", fortemente presente no cenário educacional brasileiro, trata-se de um símbolo das posições pedagógicas sintonizadas com o processo de mundialização do capitalismo e, logo, com o projeto político e econômico neoliberal e com o universo ideológico pós-moderno, originário da referida decadência ideológica. Dessa forma, concluímos que o lema "Aprender a aprender" correponde, no atual plano educacional, a um traço de continuidade dos instrumentos de manipulação ideológica da burguesia francesa de 1848 .

O poder da ideologia dominante contemporânea é imenso, ainda mais aliado ao arsenal político-cultural à disposição da classe dominante e, diante desse contexto, faz-se necessário refletir acerca de formas que, por meio da educação escolar, possam contribuir para a plena humanização do indivíduo. Acreditamos que uma dessas formas é o ensino de Literatura que, privilegiando o conhecimento clássico - aquele que integra o patrimônio cultural da humanidade e diz respeito à própria identidade do homem que se desenvolve historicamente - e, portanto, o acesso a textos cuja forma e conteúdo representem as máximas conquistas da humanidade, pode colaborar de modo significativo para a supressão dos empecilhos que a forma social capitalista vem impondo ao desenvolvimento plenamente livre e universal do homem.

\section{A PRESENÇA DA DECADÊNCIA IDEOLÓGICA NO ENSINO DE LITERATURA}

Carlos Drummond de Andrade, em sua bela crônica poética "Operário no mar", revela a situação de opressão, portanto de alienação, do operário brasileiro na década de 1930, momento em que o país enfrenta uma grande depressão causada pela quebra da bolsa de Nova York em 1929. 


\section{Revista HIIST'TEIDBR On-line}

Na rua passa um operário. Como vai firme! Não tem blusa. No conto, no drama, no discurso político, a dor do operário está na blusa azul, de pano grosso, nas mãos grossas, nos pés enormes, nos desconfortos enormes [...]. Para onde vai ele, pisando assim tão firme? (ANDRADE, 2012, p. 23).

O capitalismo já havia ingressado na era do seu desenvolvimento industrial quando o Brasil assume um projeto industrializante devido ao abalo da economia exportadora do café - cujas receitas financiavam as importações - provocado pela quebra da Bolsa de Nova York, em 1929. Essa transição da economia agrícola para a economia industrial já havia se iniciado no final do século XIX e vai se consolidar no início do século XX. Eis aí o processo de implantação do capitalismo no Brasil, que se iniciou entre os anos de 1885 e 1930 e expandiuse até 1955, quando então ocorreu a etapa da consolidação da indústria com o governo de Juscelino Kubitschek, que executou o projeto de substituição de importações atraindo, por meio de grandes vantagens, empresas estrangeiras para implantar as indústrias de bens de consumo duráveis.

[...] o Brasil, consolidou, sob a égide do modelo de substituição de importações, as indústrias de bens de consumo não duráveis até o início dos anos de $1950 \mathrm{e}$ instalou nos anos finais dessa década, no governo de Juscelino Kubitschek, as indústrias de bens de consumo duráveis. (SAVIANI, 2008a, p. 193).

Kubitschek, ao mesmo tempo em que praticava essa política econômica favorável às empresas estrangeiras, incentivava a elaboração e a difusão da ideologia política do nacionalismo desenvolvimentista, fato que acarretou uma contradição entre o modelo econômico de caráter desnacionalizante e a ideologia política nacionalista. Essa contradição esteve na base da crise dos anos iniciais da década de 1960 que culminou no internacionalismo autoritário em sua vertente militarista, ou seja, no golpe militar de 1964. A Revolução de 1964 resolveu o conflito mencionado acima ajustando a ideologia política ao modelo-econômico, ou seja, ocorreu uma ruptura no nível político e não no âmbito socioeconômico para que pudesse ser preservada a ordem socioecômica. Saviani (2008a, p. 364) explica essa questão:

\footnotetext{
O golpe militar desencadeado em 31 de março consumou-se em $1^{\circ}$ de abril. Diante da alternativa: ajustar a ideologia política ao modelo econômico ou vice-versa, a Revolução de 1964 resolveu o conflito impondo a primeira opção. E a ideologia do nacionalismo desenvolvimentista foi substituída pela doutrina da interdependência.

$[\ldots]$

A ruptura deu-se no nível político e não no âmbito socioeconômico. Ao contrário, a ruptura política foi necessária para preservar a ordem socioeconômica, pois se temia que a persistência dos grupos que então controlavam o poder político formal viesse a provocar uma ruptura no plano socioeconômico. [...] Mas no plano político foi inegável a "mudança radical" atestada até mesmo pelo simples fato da permanência dos militares no poder, caso inédito na história da política brasileira.
}

Houve, portanto, uma continuidade no plano socioeconômico e tal fato refletiu, como atesta Saviani, na legislação que instituiu as reformas de ensino baixadas pela ditadura militar, ou seja, as bases organizacionais foram modificadas a fim de adequar a educação brasileira às exigências do modelo econômico do capitalismo de mercado associado dependente, articulado com a doutrina da interdependência. $\mathrm{O}$ aprofundamento das relações capitalistas, no Brasil, implicou a compreensão de que a educação poderia ser uma aliada ao 


\section{Revista HIIST'TEIDBR On-line}

Artigo

doi: $10.20396 /$ rho.v17i3.8645880

desenvolvimento e consolidação dessas relações, ou seja, levou à defesa da organização do sistema de ensino em estreita vinculação com o desenvolvimento econômico do país.

Para o educador brasileiro (2008a), o emprego do modelo econômico associadodependente, o ingresso de empresas estrangeiras, a demanda de preparação de mão de obra para estas levou à importação do modelo organizacional que as presidia no campo da educação. Propagaram-se, então, ideias ligadas à organização racional do trabalho, ao enfoque sistêmico e ao controle do comportamento que, no âmbito da educação, caracterizaram uma orientação pedagógica chamada de pedagogia tecnicita, a qual foi convertida em pedagogia oficial do país. Saviani (2008a, p. 381-382) menciona as características dessa orientação pedagógica:

Com base no pressuposto da neutralidade científica e inspirada nos princípios de racionalidade, eficiência e produtividade, a pedagogia tecnicista advoga a reordenação do processo educativo de maneira que o torne objetivo e operacional. De modo semelhante ao que ocorreu no trabalho fabril, pretende-se a objetivação do trabalho pedagógico.

A Revolução de 1964 ajustou a ideologia do nacionalismo desenvolvimentista ao modelo-econômico a fim de preservar a ordem socioecômica e tal fato, como afirma Saviani (2008a), repercutiu na legislação que instituiu as reformas de ensino baixadas pela ditadura militar, ou seja, as bases organizacionais foram modificadas para adaptar a educação brasileira às exigências do modelo econômico do capitalismo de mercado associado dependente, ligado à doutrina da interdependência. O enraizamento das relações capitalistas, no Brasil, acarretou a compreensão de que a educação deveria ser uma aliada ao desenvolvimento e consolidação dessas relações, ou seja, levou à defesa da organização do sistema de ensino em íntima associação ao desenvolvimento econômico do país. Segundo Saviani (2008a, p. 367), com o advento do regime militar, o lema positivista "Ordem e progresso" inscrito na bandeira brasileira transformou-se em "[...] segurança e desenvolvimento".

De acordo com Saviani (2008a), é sob o esteio do governo ditatorial, que se dá a elaboração e a aprovação do projeto da Lei 5.692, de 11 de agosto de 1971, que instituiu as diretrizes e bases do ensino de primeiro e segundo graus, reformando o antigo ensino primário e médio e convertendo a pedagogia tecnicista em pedagogia oficial do país. Para o autor (1986), essa lei define como objetivo do ensino de $2^{\circ}$ grau a formação integral do adolescente; porém propõe uma estrutura didático-pedagógica segundo a qual o currículo terá uma parte de educação geral e outra de formação especial. A formação especial, predominante no ensino de $2^{\circ}$ grau, trata-se da habilitação profissional e tal fato, para Saviani (1986), nos coloca uma questão: a ênfase na habilitação profissional é compatível com a formação integral do adolescente?

Em relação ao ensino de Língua Portuguesa nesse contexto ideológico, a língua passa a ser considerada como instrumento a serviço do desenvolvimento. Com a promulgação da Lei $n^{\circ}$ 5692/71, a denominação da disciplina escolar Português ou Língua Portuguesa passa a ser Comunicação e Expressão, nas quatro primeiras séries do $1^{\circ}$ grau; Comunicação em Língua Portuguesa, nos quatro últimos anos do $1^{\circ}$ grau; e "Língua Portuguesa e Literatura Brasileira", no $2^{\circ}$ grau. Essa lei determinava que se devia dar relevo especial à língua nacional, compreendida como instrumento de comunicação e expressão da cultura brasileira. 


\section{Revista HIIST'TEIDBR On-line}

Artigo

doi: $10.20396 /$ rho.v17i3.8645880

O ensino de Literatura não é especificado no documento da lei, mas pode ser incluído na referência à cultura brasileira, o que nos faz concluir que se trata apenas da literatura brasileira. Aproximadamente até o final de 1960, a escola brasileira sugeria a literatura como o padrão de norma lingüística a ser seguido, de modo que os livros didáticos dauqela época conservavam textos e fragmentos de autores considerados clássicos. A gramática normativa apresentava suas regras e, para exemplificá-las, utilizavam-se também dos clássicos. A relação entre a norma culta da língua e a linguagem literária clássica era evidente, mas com promulgação da referida lei o ensino de gramática é questionado e passa a ser minimizado, o ensino da Língua Portuguesa vai se desvencilhando da influência da literatura clássica exercida desde a introdução dessa disciplina no currículo escolar - e, consequentemente, o conteúdo passa a ser esvaziado, fato que se agrava no decorrer das próximas décadas.

Nos anos 70, o ensino de Literatura restringiu-se ao $2^{\circ}$ grau por meio de abordagens historiográficas e estruturalistas do texto literário. A análise do texto poético era realizada conforme as estruturas formais: rimas, escansão de versos, ritmo, estrofes, entre outros. Tanto o estudo historiográfico quanto o da estrutura formal do texto são de extrema importância para a compreensão de grandes obras literárias, mas essas abordagens apenas não bastam para que a obra possa de fato contribuir para formar no aluno as atitudes e ações que colocam o processo da recepção estético-literária à altura da riqueza contida na obra.

No referido documento, a alusão feita à Língua Portuguesa e à Literatura Brasileira revela uma separação entre o ensino de gramática e o de literatura e a exclusão do ensino de literatura portuguesa. Essa separação acentuou a tendência marcada pelo espírito tecnicista de dividir conteúdos e professores de uma mesma disciplina para especializar e, consequentemente, fragmentar o ensino. Dessa forma, para o ensino de Língua surgiram professores de gramática, de literatura e de redação com materiais didáticos e métodos de avaliação específicos.

Muitos educadores repeliram essa educação oficial e procuraram relacionar suas críticas ao regime militar, autoritário e tecnocrático, e a seu plano educacional. Nesse mesmo panorama em que predominava a linguagem da economia, também emergia uma visão da escola iluminada pela perspectiva crítico-reprodutivista, ou seja, a escola passa a ser encarada como um meio de reprodução das desigualdades sociais e culturais. A política educacional do regime militar passou a ser vista como um instrumento de controle da sociedade que visava perpetuar as relações de dominação vigentes.

De acordo com Saviani (2008a), tal visão desempenhou um relevante papel na década de 1970, pois suas análises constituíram-se em armas teóricas utilizadas para fustigar a política educacional do regime militar, a qual buscava fazer da escola uma forma de controle da sociedade para que se perpetuassem as relações de dominação vigentes. Tais teorias, portanto, criticavam a educação vigente, mas não apresentavam alternativas, ou seja, não propunham novas políticas educacionais.

A ditadura militar chega ao fim com o processo de redemocratização do país nos anos de 1980, mas esse movimento de reabertura política vem acompanhado de imposições mundiais, caracterizadas pela globalização da economia na perspectiva neoliberal; portanto, conforme afirma Saviani (2008a), a transição democrática não significou a descontinuidade da ordem socioeconômica. Nessa mesma década, desponta com força a busca de teorias que não apenas se apresentassem como alternativas à pedagogia oficial, mas que a ela se 


\section{Revista HIIST'TEIDBR On-line}

contrapusessem. A despeito do clima propício à emergência das pedagogias contrahegemônicas na década de 1980, os resultados não foram animadores, pois as tentativas de implantar políticas educativas de esquerda por parte de governos estaduais e municipais foram frustrantes.

Como já dissemos, segundo Saviani (SAVIANI, 2008a), na década de 1990, há a ascensão de governos ditos neoliberais, são promovidas em diversos países reformas educativas caracterizadas pelo neoconservadorismo e, dessa forma, o discurso e a prática governamentais brasileiros reconstituem a aliança entre educação e desenvolvimento econômico. Reformas educacionais são efetuadas conforme diretrizes de organismos internacionais e com isso se dá a atualização do lema "Aprender a aprender", o qual influenciará sobremaneira o ensino de Língua Portuguesa e, logo, o de Literatura.

A lei 9394/96, publicada durante a ascensão dos governos neoliberais no Brasil, no caso do governo de Fernando Henrique Cardoso, organiza o currículo escolar em duas partes, ou seja, em uma base nacional comum e uma parte diversificada. Essa nova lei faz referência também ao ensino de Português, mas, conforme atesta Cereja (2005), o faz de modo muito vago.

Art. 36. O currículo do ensino médio observará o disposto na Seção I deste Capítulo e as seguintes diretrizes:

I - destacará a educação tecnológica básica, a compreensão do significado da ciência, das letras e das artes; o processo histórico de transformação da sociedade e da cultura; a língua portuguesa como instrumento de comunicação, acesso ao conhecimento e exercício da cidadania [...].

De acordo com Cereja (2005), a menção ao ensino de Literatura se encontra na alusão às "letras" e ao "processo histórico de transformação da sociedade e da cultura" e a referência ao ensino de língua está presente no trecho "língua portuguesa como instrumento de comunicação".

O lema “aprender a aprender" é expresso no artigo 35, item II, dessa lei:

II - a preparação básica para o trabalho e a cidadania do educando, para continuar aprendendo, de modo a ser capaz de se adaptar com flexibilidade a novas condições de ocupação ou aperfeiçoamento posteriores. (BRASIL, 1996, p. 32).

Em 1997, para poder esmiuçar os propósitos da reforma educacional e orientar os docentes acerca das especificidades de sua disciplina, o governo federal divulgou os Parâmetros Curriculares Nacionais $(\mathrm{PCN})$ destinados ao fundamental. Os parâmetros Curriculares Nacionais - Ensino Médio (PCNEM), na área de "Linguagens, Códigos e suas Tecnologias", foram divulgados em 1999, mas, segundo Cereja (2005), repercutiram pouco no âmbito educacional devido ao fato de se tratar de um documento breve cuja proposta de ensino de língua e literatura é inovadora, porém não desenvolvida. O documento, ao abordar o papel das linguagens, assim se posiciona:

Utilizar-se das linguagens como meio de expressão, informação e comunicação em situações intersubjetivas, que exijam graus de distanciamento e reflexão sobre os contextos e estatutos de interlocutores; e saber colocar-se como protagonista no processo de produção/recepção. (BRASIL, 1999, p. 23). 


\title{
Revista HIISTEYIDIR On-line
}

Para Cereja (2005), nesse documento, a ênfase quanto ao papel social das linguagens recai na concepção segundo a qual a linguagem é um "meio de expressão, informação e comunicação". E as referências feitas ao ensino de Literatura na parte de "Conhecimentos de Língua Portuguesa" são duas:

\begin{abstract}
Os estudos literários seguem o mesmo caminho. A história da literatura costuma ser o foco da compreensão do texto; uma história que nem sempre corresponde ao texto que lhe serve de exemplo. O conceito de texto literário é discutível. Machado de Assis é literatura, Paulo Coelho não. Por quê? As explicações não fazem sentido para o aluno. (MEC, 1999, p. 34.)
\end{abstract}

Os conteúdos tradicionais de ensino de língua, ou seja, nomenclatura gramatical e história da literatura, são deslocados para um segundo plano. O estudo da gramática passa a ser uma estratégia para compreensão/ interpretação/ produção de textos e a literatura integra-se à área de leitura. (MEC, 1999, p. 38.)

De acordo com o segundo excerto, no novo ensino, a história da literatura se desloca para segundo plano e o ensino de literatura se integra à leitura de texto. Apesar desse apontamento, tal documento não expõe com clareza em que consistiria o novo ensino de literatura, não define que textos literários deveriam compor uma antologia a ser trabalhada em aula. Para Cereja (2005), as quatorze páginas apenas desse documento destinadas aos "Conhecimentos de Língua Portuguesa" realizam críticas ao ensino de gramática e de literatura, mas não oferecem subsídios suficientes para estimular o professor a fazer uma revisão profunda tanto de seus métodos de ensino quanto do currículo escolar.

Ainda segundo Cereja (2005), a falta de um rumo claro no que diz respeito ao ensino de literatura e a insatisfação em relação ao documento, provenientes de diferentes esferas educacionais e sociais, fez com que o MEC providenciasse a publicação dos Parâmetros Curriculares Nacionais + Ensino Médio $(\mathrm{PCN}+)$; com o subtítulo de Orientações educacionais complementares aos Parâmetros Curriculares Nacionais, a fim de explicar ou desenvolver alguns trechos dos PCNEM. Mas, conforme atesta Cereja (2005, p. 119), a falta de clareza para definir os rumos pretendidos para o ensino de Língua Portuguesa e, consequentemente, de Literatura, no ensino médio, permanecem; pois o novo documento deixa dúvidas por recuar em relação a algumas posições assumidas pelo documento anterior, como no caso do ensino de história da literatura que, de acordo com os PCNEM, deveria ocupar papel secundário, dando maior espaço para formação de leitores de literatura. Nos $\mathrm{PCN}+$, o enfoque da questão do ensino da história da literatura parece ser diferente do dos PCNEM.

\footnotetext{
A língua, bem cultural e patrimônio coletivo, reflete a visão de mundo de seus falantes e possibilita que as trocas sociais sejam significadas e ressignificadas. No domínio desse conceito está, por exemplo, o estudo da história da literatura, a compreensão do dinamismo da língua, a questão do respeito às diferenças linguísticas, entre outros. (BRASIL, 2002, p. 66).
}

A formação do aluno deve propiciar-lhe a compreensão dos produtos culturais integrados a seu(s) contexto(s) - compreensão que se constrói tanto pela retrospectiva histórica quanto pela presença desses produtos na contemporaneidade. (BRASIL, 2002, p. 69). 


\section{Revista HIIS'TEIDBR On-line}

[Considera-se mais significativo que] o ensino médio dê especial atenção à formação de leitores, inclusive das obras clássicas de nossa literatura, do que mantenha a tradição de abordar minuciosamente todas as escolas literárias, com seus respectivos autores e estilos. (BRASIL, 2002, p. 71).

Exceto o último trecho transcrito, todos os outros pressupõem a inclusão da história da literatura no programa escolar, admitindo, portanto, procedimentos antes questionados pelo PCNEM. Nos excertos acima, a novidade, em relação às práticas de ensino de literatura, parece estar nas palavras minuciosamente e todas, ou seja, o documento parece admitir que se deva trabalhar com a história da literatura, mas sem que haja a obrigatoriedade de abordar minuciosamente todas as escolas literárias e seus respectivos autores. Segundo Cereja (2005), o documento admite também o trabalho com as obras literárias clássicas, apesar das críticas realizadas pelos PCNEM acerca do cânone literário, conforme o trecho reproduzido anteriormente.

[...] A história da literatura costuma ser o foco da compreensão do texto; uma história que nem sempre corresponde ao texto que lhe serve de exemplo. $O$ conceito de texto literário é discutível. Machado de Assis é literatura, Paulo Coelho não. Por quê? As explicações não fazem sentido para o aluno. (MEC, 1999, p. 34).

Dessa forma, podemos concluir que tanto os PCNEM quanto os PCN+ não deixam nítido o modo como o docente deve proceder em relação ao cânone literário. Ambos os documentos necessitam de maior discussão e de revisão, a fim de ajustar os pressupostos teórico-metodológicos.

Independente dessa necessária revisão dos documentos acima discutidos, podemos afirmar que tais leis foram promulgadas após a ascensão de governos neoliberiais no Brasil e, no âmbito educacional, dão continuidade ao projeto de adequação do Brasil aos moldes ditados pelo capitalismo mundializado. Há, nesses documentos acima mencionados, a presença do lema "aprender a aprender" e, segundo Duarte (2006), a adesão a esse lema implica a adesão a todo um ideário educacional afinado à lógica da sociedade capitalista contemporânea.

Tais documentos, ao preconizarem que o aluno deva ser o protagonista do processo de aprendizagem, revelam sua relação com o lema "aprender a aprender" que, de acordo com Duarte (2006), é a expressão da descaracterização do papel do professor como alguém que detém um saber a ser transmitido aos alunos porque considera mais importante o aluno desenvolver um método de aquisição de conhecimento do que aprender conhecimentos que foram descobertos e elaborados por outras pessoas.

Essa desvalorização da função do docente prejudica gravemente o processo educacional de modo geral e, logo, o ensino de Literatura, porque, como afirma Saviani (2008b), há uma diferença entre o modo como o professor se relaciona com a sociedade e o processo educativo e o modo como o aluno se relaciona, ou seja, a relação do aluno se dá, predominantemente, de forma sincrética, enquanto a relação do professor se dá de forma sintética ${ }^{3}$. O processo pedagógico, para Saviani (2008b), deve possibilitar que o professor realize a mediação entre o aluno e o conhecimento que se desenvolveu socialmente e que, assim, no ponto de chegada o aluno se aproxime do professor, podendo também estabelecer uma relação sintética com o conhecimento da realidade. Portanto, sem a efetiva mediação 


\section{Revista HIIST'TEIDBR On-line}

Artigo

doi: $10.20396 /$ rho.v17i3.8645880

do professor no processo educacional, a concepção de mundo do aluno pode se manter atrelada a uma visão caótica da realidade.

Outras características dos documentos mencionados que revelam seu comprometimento com o lema "aprender a aprender" são a exclusão do ensino de Literatura Portuguesa e o deslocamento da história da literatura para segundo plano, relacionando o ensino de Literatura apenas à leitura de textos literários. Essas características denotam o núcleo definidor do lema "aprender a aprender": a negação do ato de ensinar, o rebaixamento da transmissão do saber objetivo. "A essência do lema 'aprender a aprender' é exatamente o esvaziamento do trabalho educativo escolar, transformando-o num processo sem conteúdo". (DUARTE, 2006, p. 9).

De acordo com Duarte (2006), o universo ideológico no qual estão inseridas as proposições pedagógicas presentes nos PCN é o universo neoliberal e pós-moderno e tal fato se torna nítido se consideramos que a separação entre o ensino da Língua Portuguesa e o de Literatura acentuou a tendência pautada pelo espírito tecnicista de dividir conteúdos e professores de uma mesma disciplina fragmentando o ensino, pois a fragmentação do conhecimento é um aspecto típico do ideário pós-moderno.

A exclusão do ensino de Literatura Portuguesa, a secundarização do ensino de história de literatura, a fragmentação do conhecimento da disciplina de Língua Portuguesa e a concepção da linguagem como uma mera ferramenta para a construção de significados e conhecimentos é considerar as formas do processo pedagógico em si mesmas em detrimento do conteúdo. Saviani (2008b, p. 144) explica essa relação entre forma e conteúdo na prática educativa:

[...] a questão pedagógica, em sua essência, é a questão das formas. Estas, porém, nunca podem ser consideradas em si mesmas. E a diferenciação sempre se dará pelo conteúdo. Se for feita a abstração dos conteúdos, fica-se com a pura forma. Aí ocorre a indiferenciação. É nesse sentido que os conteúdos são importantes. Tratar as formas em concreto e não em abstrato é tratá-las pela via dos conteúdos. Isso pode ser constatado de modo claro quando consideramos as disciplinas que compõem o currículo escolar. Tome-se, por exemplo, o caso da história. Se o fundamental é que o aluno aprenda o método, ou seja, como se situar historicamente, como apreender o movimento da história, então se trata aí do método da história. Ele só irá apreender isso através da familiaridade com a história propriamente dita. Logo, com os conteúdos históricos.

Em relação ao ensino de história de literatura, podemos dizer, como atesta Saviani (2008b), que os conteúdos históricos sempre serão relevantes e determinantes, porque é por meio deles que se apreende a perspectiva histórica, o modo de situar-se historicamente. $\mathrm{O}$ conteúdo histórico no ensino de literatura pode contribuir efetivamente para que o aluno tenha uma visão totalizadora do que antes era visto de modo fragmentado.

Diante do exposto, acreditamos que os documentos abordados proclamam um ensino de Língua Portuguesa e, portanto, de Literatura, cujo comprometimento não é com a plena formação dos indivíduos e sim com a ideologia da classe dominante para esvaziar a educação escolar destinada à maioria da população; pois tais documentos estão pautados no lema "Aprender a aprender" que, como vimos, trata-se de um símbolo das posições pedagógicas sintonizadas com o processo de mundialização do capitalismo e, logo, com o projeto político 


\section{Revista HIIST'TEIDBR On-line}

e econômico neoliberal e com o universo ideológico pós-moderno, originário da mencionada decadência ideológica burguesa.

Dessa forma, podemos atestar que, se o lema "Aprende a aprender" pauta as atuais concepções de ensino de Língua Portuguesa, tal ensino vem carregando nas últimas décadas a influência do ideário pós-moderno, sombra da decadência ideológica burguesa do século XIX marcadamente presente nos atuais parâmetros curriculares nacionais.

É perante esse contexto que defendemos a necessidade de se pensar em um ensino de Língua Portuguesa e, no caso do foco desse artigo, em um ensino de Literatura que vá de encontro à ampla difusão das teorias epistemológicas, psicológicas e pedagógicas de cunho construtivista, expressões, no campo educacional, da decadência ideológica do pensamento burguês. É diante desse panorama que preconizamos um ensino de literatura comprometido com a socialização da literatura clássica, com o domínio do saber objetivo nas suas formas mais desenvolvidas e com a ampliação dos horizontes culturais dos alunos. Precisamos pensar em um ensino de Literatura que transmita aqueles conhecimentos que, tendo sido produzidos por seres humanos concretos em momentos históricos específicos, alcançaram validade universal. Enfim, há a necessidade de se refletir acerca de um ensino de literatura compromissado com um conhecimento que possibilite ao aluno vivenciar esteticamente uma obra literária e, pela recepção estético-literária, enriquecer-se eticamente, afinar seus sentidos, transformar sua concepção de mundo em uma visão desfetichizada da realidade, enfim, humanizar-se.

\section{A LITERATURA CLÁSSICA SOB À LUZ DA ESTÉTICA MARXISTA}

Para elucidarmos como o ensino de literatura pode contribuir para a formação humana, recorremos à estética marxista, portanto, apoiamo-nos na concepção filosófica de realismo crítico de Lukács para discorrermos sobre as principais características da literatura clássica e para realizarmos demais análises relacionadas ao tema.

Para Lukács (2011a), a grande arte realista é aquela que sobrevive nas malhas da história e que possui elevado patamar estético. A arte aplicada ao realismo, de acordo com o filósofo, não diz respeito a um estilo artístico, mas sim à reprodução artística da realidade, à fidelidade ao real, ao esforço apaixonado para reproduzi-lo na sua integridade e totalidade. Conforme explica Frederico (2015, p. 108), “[...] o realismo é, então, entendido como um método para figurar a realidade, uma atitude do escritor presente em toda a história, dos gregos aos dias de hoje, e não uma escola literária".

De acordo com Lukács (1970), a articulação da obra literária aos grandes problemas do desenvolvimento da humanidade é o que a torna valorosa ao longo da história e permite que seja considerada realista. Conforme as nossas apropriações das produções do filósofo húngaro, a nossa concepção de literatura clássica equivale ao que, para o autor marxista (2010), trata-se das grandes obras-primas da literatura mundial, isto é, da literatura que se pronuncia realista.

Com base na concepção lukacsiana, podemos dizer que a literatura clássica é aquela que habilita os homens a perceberem o mundo como ele efetivamente é ao projetar uma realização da realidade como totalidade, isto é, ao desvelar as antinomias do real. A literatura 
clássica busca compreender do modo mais fiel possível a realidade em sua totalidade dinâmica e contraditória e, por isso, objetiva realizar as mediações entre o destino de seus personagens singulares e os grandes conflitos sociais nos quais eles estão inseridos.

A obra literária clássica trata-se de uma arte que move a subjetividade individual rumo às formas mais ricas de subjetividade já desenvolvidas pelo gênero humano, ou seja, apresenta ao sujeito receptor situações nas quais decisivas experiências humanas despontam intensificadas e configuradas de modo que consigam impelir o leitor a compreender-se na totalidade do mundo, subjugar seu modo habitual de contemplar o mundo, impor-lhe - por meio do efeito catártico - uma nova concepção de mundo que lhe fortaleça a consciência de si e a sua responsabilidade em relação aos problemas da esfera pública.

Lukács (1966b) encara a catarse como um momento durante o qual o sujeito se vê perante a necessidade de questionar sua visão da vida e de si mesmo e tal efeito se dá pela obra de arte porque esta, pela sua universalidade, aproxima o homem do gênero humano. A catarse, assim, é analisada como um processo de desenvolvimento do indivíduo em direção a uma relação cada vez mais consciente com o gênero humano.

Dessa forma, podemos dizer que a literatura clássica é capaz de suscitar o efeito catártico porque pode despertar nos sujeitos a consciência sensível de que a vida individual e a vida do gênero são interdependentes, porque se dirige à condição do ser humano, porque realiza uma crítica à vida e, portanto, porque é capaz de convocar o leitor a descobrir os laços que unem sua vida à do gênero humano.

A literatura, forma de expressão artística pode exercer um papel desfetichizador na formação humana, portanto, pode contribuir de modo significativo para a construção de uma pedagogia marxista que vise à humanização dos indivíduos. Defendemos, portanto, que, no ensino de Literatura, deva estar presente a literatura clássica, pois acreditamos que tal literatura seja capaz de provocar o efeito catártico no aluno, isto é, capaz de mover a sua subjetividade individual rumo às formas mais ricas de subjetividade já desenvolvidas pelo gênero humano.

\section{O ENSINO DE LITERATURA: POSSÍVEL CONTRIBUIÇÃO PARA A HUMANIZAÇÃO DO INDIVÍDUO}

De acordo com Saviani (2000, p. 89), “[...] a pedagogia é o processo através do qual o homem se torna plenamente humano". Para o educador brasileiro $(2000$, p. 17), “[...] o trabalho educativo é o ato de produzir, direta e intencionalmente, em cada indivíduo singular, a humanidade que é produzida histórica e coletivamente pelo conjunto dos homens". Dessa forma, segundo o autor, o objeto da educação se refere tanto à identificação dos elementos culturais que devem ser assimilados pelos homens para que se humanizem quanto à descoberta das formas mais adequadas para atingir esse objetivo. Saviani (2000, p. 17-18) explica melhor esses objetos da educação e expõe a importância da noção de clássico para a educação escolar:

Quanto ao primeiro aspecto (a identificação dos elementos culturais que precisam ser assimilados), trata-se de distinguir entre o essencial e o acidental, o principal e o secundário, o fundamental e o acessório. Aqui me parece de grande importância, em pedagogia, a noção de "clássico". O clássico não se confunde com o tradicional 


\section{Revista HIIS'TEIDBR On-line}

e também não se opõe, necessariamente, ao moderno e muito menos ao atual. O clássico é aquilo que se firmou como fundamental, como essencial. Pode, pois, constituir-se num critério útil para a seleção dos conteúdos do trabalho pedagógico.

Quanto ao segundo aspecto (a descoberta das formas adequadas de desenvolvimento do trabalho pedagógico), trata-se da organização dos meios (conteúdos, espaço, tempo e procedimentos) através dos quais, progressivamente, cada indivíduo singular realize, na forma de segunda natureza, a humanidade produzida historicamente.

Para Saviani (2008b), clássico é o que resistiu ao tempo e, na escola, clássico é a transmissão-assimilação do saber sistematizado que precisa ser dosado e sequenciado de uma forma que o educando passe gradativamente do seu não-domínio para o seu domínio. "[...] o saber dosado e sequenciado para efeitos de sua transmissão-assimilação no espaço escolar, ao longo de um tempo determinado, é o que nós convencionamos chamar de saber escolar". (SAVIANI, 2008b, p. 18).

Com base na concepção da pedagogia histórico-crítica, a "escola existe [...] para propiciar a aquisição dos instrumentos que possibilitam o acesso ao saber elaborado [...]" e, assim, pela mediação da escola, "[...] acontece a passagem do saber espontâneo ao saber sistematizado, da cultura popular à cultura erudita", que, conforme atesta Saviani, é a que possibilita a apropriação de novas formas por meio das quais o indivíduo pode expressar os próprios conteúdos do saber popular. (SAVIANI, 2008b, p. 15; 21-22). Saviani (2008b, p. 9), resume a tarefa a que se propõe a pedagogia histórico-crítica em relação à educação escolar:

a) Identificação das formas mais desenvolvidas em que se expressa o saber objetivo produzido historicamente, reconhecendo as condições de sua produção e compreendendo as suas principais manifestações, bem como as tendências atuais de transformação.

b) Conversão do saber objetivo em saber escolar, de modo que se torne assimilável pelos alunos no espaço e tempo escolares.

c) Provimento dos meios necessários para que os alunos não apenas assimilem o saber objetivo enquanto resultado, mas apreendam o processo de sua produção, bem como as tendências de sua transformação.

Desse modo, a pedagogia histórico-crítica defende que a escola deve ser o lugar da socialização do conhecimento que, segundo Duarte (2012), é de extrema importância na luta contra o capital e na busca da formação plena do ser humano. "A luta pela socialização do conhecimento é, portanto, um componente imprescindível da luta contra o capital". (DUARTE, 2012, p. 154). Assim, conforme afirma Duarte, o papel da escola relaciona-se à formação plena dos seres humanos, pois a transmissão do conhecimento científico, artístico e filosófico é de imensa relevância quando se objetiva a constituição da individualidade livre e universal dos homens, ou seja, a formação do indivíduo para-si.

A pedagogia histórico-crítica tem, entre outros objetivos, o propósito de lutar pela valorização da transmissão do saber objetivo - as formas mais desenvolvidas e ricas do conhecimento até aqui produzido pela humanidade - pela escola, pelo fortalecimento da função da escola de proporcionar ao educando o acesso à verdade. A pedagogia históricocrítica, desse modo, compromete-se com a verdade e esta, como atesta Saviani (2008b), é sempre revolucionária. Tal teoria fornece a nós, educadores, subsídio para resistirmos às 


\section{Revista HIIST'TEIDBR On-line}

políticas educacionais que apontam em direção à descaracterização da escola, para rejeitarmos os discursos que secundarizam a transmissão do conhecimento tão necessário para a humanização plena do indivíduo, para nos defendermos das ofensivas advindas da ordem social capitalista.

Portanto, é com base nessa pedagogia que abordaremos um ensino de Literatura capaz de transmitir aos alunos o conhecimento artístico-literário em suas formas mais desenvolvidas. Apoiar-nos-emos na pedagogia histórico-crítica para pensarmos em um ensino de literatura que contribua para que os alunos se apropriem de alguns elementos culturais necessários à sua formação como ser humano, vivam momentos catárticos proporcionados pela educação e pela obra literária, se reconheçam como agentes e autores da vida social com suas instituições e, conscientes de seu pertencimento ao gênero humano, possam se desalienar, mesmo que em graus diferentes, e perceberem que a emancipação dos homens será obra histórica dos próprios homens.

A breve análise das opções metodológicas que têm norteado o trabalho com a literatura no Ensino Médio nas últimas décadas aponta diversas ênfases para o trabalho com o texto literário. A literatura já foi apresentada como história, como arte e como linguagem. O problema consiste em que cada uma dessas abordagens, ao privilegiar determinado aspecto do texto literário, deixa outros tantos na sombra ou não os articula entre si de modo suficiente.

Conforme afirmam Maria Luiza M. Abaurre e Marcela Pontara (2010), é necessário, antes de mais nada, reconhecer os objetivos associados às aulas de literatura no Ensino Médio. Propor o contato com um relevante repertório artístico e cultural criado pelos seres humanos ao longo de sua trajetória é um objetivo que deve ser definido e a realização deste implica pôr à disposição dos alunos conceitos e informações que os ajudem a compreender o contexto discursivo em que um determinado texto foi escrito para, dessa forma, terem condições de atribuir sentido ao que leem, mesmo que séculos separem o momento de leitura do momento de criação de um texto.

Para tanto, segundo Abaurre e Pontara (2010), precisamos apontar uma abordagem que revele como as diferentes dimensões do texto literário se articulam para dar forma a um projeto literário específico. E tratar a literatura como um discurso pode ser um caminho, pois no âmbito dos estudos da linguagem a análise do discurso utiliza o termo discurso para se referir ao uso da língua em um contexto específico. De acordo com essa perspectiva, ao invés de tratar somente dos fatores linguísticos, a análise do discurso interessa-se pela relação entre os usos da língua e os fatores extralinguísticos presentes no momento em que esse uso ocorre. Nesse sentido, tratar da língua que está em uso pelos seres humanos denota tratar da sua dimensão discursiva.

Segundo as autoras, um dos aspectos mais importantes do estudo da literatura é a análise de como os escritores empregam a língua para sua criação artística; e, para efetivar tal estudo, podemos focalizar as escolhas específicas (lexicais ou sintáticas, por exemplo) que caracterizam o texto de um determinado autor ou de uma dada estética. Esse olhar evidenciará relevantes aspectos do texto literário, mas propomos ainda ir além desse processo analítico, ou seja, uma vez identificados os usos particulares da língua que definem um movimento estético determinado (ou a obra de um autor específico), indagar que relação os fatores extralinguísticos presentes naquele momento têm com tais escolhas. 


\section{Revista HIIST'TEIDBR On-line}

Artigo

doi: $10.20396 /$ rho.v17i3.8645880

Concordamos com as autoras que no ensino de literatura deva haver a busca pela articulação entre os diferentes agentes do discurso para que o aluno possa compreender por que, em um determinado momento da história, a criação literária se realiza por meio de características específicas, seja na escolha dos temas abordados, seja no modo como a linguagem é utilizada pelos escritores. Expor ao aluno a articulação entre os diferentes agentes do discurso o auxiliará a identificar e compreender o projeto literário de cada uma das estéticas a serem estudadas ao longo do Ensino Médio.

Levantar informações sobre o público a que se destinam as obras produzidas em um determinado momento histórico e reconhecer as características do contexto no qual estavam inseridos os escritores faz com que, durante o estudo proposto, sejam destacadas as forças que determinam a eleição de algumas características estéticas que explicam determinados usos da linguagem, que revelam as intenções dos diferentes projetos literários. Reconhecer como a literatura descortina o passado e como nos permite identificar a visão de mundo e o sistema de valores em distintos momentos dá significado ao ensino de literatura, pois, assim, o aluno estabelece um contato com:

[...] um sistema vivo de obras, agindo umas sobre as outras e sobre os leitores; [que] só vive na medida em que estes a vivem, decifrando-a, aceitando-a, deformando-a. A obra não é produto fixo, unívoco ante qualquer público; nem este é passivo, homogêneo, registrando uniformemente o seu efeito. São dois termos que atuam um sobre o outro, e aos quais se junta o autor, termo inicial desse processo de circulação literária, para configurar a realidade da literatura atuando no tempo. (CANDIDO, 2000, p. 68).

Antonio Candido, crítico literário, pergunta ainda: o sistema autor-obra-leitores pressupõe ou motiva quais relações humanas? Essa questão pode ser o ponto capaz de dar sentido ao estudo da literatura, capaz de humanizá-lo. Pois, além de possibilitar uma visão mais articulada dos distintos aspectos que se manifestam no texto literário, cremos que tal método também instigue o aluno a voltar seu olhar para as relações, em lugar de associar movimentos estéticos a uma série de características aparentemente casuais ou arbitrárias. De acordo com Abaurre e Pontara (2010), reconhecer relações denota compreender a criação artística como um processo constante em que obras, autores e público dialogam entre si e nesse sentido, não importa se o autor a ser estudado viveu no século VII a.C., XIX ou XXI.

Devido ao fato de observarmos, frequentemente, no ensino de literatura, uma grande preocupação em enfatizar o trabalho com a linguagem ou a discussão dos valores estéticos dos textos literários, sem que o aluno seja convidado a reconhecer ou analisar de que modo tais textos nos falam sobre seres humanos ou nos revelam a humanidade de seus autores, apontamos a necessidade de enfatizar a importância do ensino da história da literatura, pois, conforme afirma Saviani (2008b), é por meio desse conhecimento que o aluno compreenderá determinados textos, autores e épocas e apreenderá a perspectiva histórica, o modo de situarse historicamente.

Conforme afirma Cereja (2005), a historicidade da literatura não constitui o problema central do ensino de literatura em nosso país, pois o problema é que, transformando-a no principal objetivo do curso de literatura no ensino médio, ela vem centralizando a maior parte das atividades da disciplina, ou seja, o estudo do contexto histórico vem se restringindo 


\section{Revista HIIST'TEIDBR On-line}

à enumeração e a um rápido comentário dos fatos mais importantes do período enfocado, sem que sejam estabelecidas relações efetivas entre a obra literária e o contexto.

A perspectiva que defendemos para um ensino de literatura humanizador não procura supervalorizar nem os elementos internos nem os elementos externos da obra literária. Busca, ao invés disso, apontar a relação existente entre eles a fim de que a historicidade do texto literário seja preservada sem perder sua especificidade estética, para que o aluno tenha, nas aulas de literatura, a noção de conjunto sem perder a de particularidade; pense o nacional sem deixar de notar suas relações com o universal.

Dessa forma, discordamos de uma metodologia que secundarize o ensino de história de literatura e, consequentemente, elimine o ensino de literatura portuguesa que constitui uma das bases para que se possa compreender a literatura brasileira. Há que se fazer uso desse conhecimento histórico de modo que ele elucide ao aluno as pegadas humanas dos antepassados numa obra literária e, assim, este possa entrever outros homens inseridos em outras civilizações, reconhecer-se humano e compreender que faz parte da história da humanidade. O texto literário é um rico material tanto para a apropriação de conhecimento quanto para a discussão e reflexão acerca de temas que abrangem as relações humanas. A obra literária, portanto, possui um papel pedagógico, um papel humanizador, como afirma Candido (1989, p. 117):

\footnotetext{
As produções literárias, de todos os tipos e todos os níveis, satisfazem necessidades básicas do ser humano, sobretudo através dessa incorporação, que enriquece a nossa percepção e a nossa visão do mundo. [...]. Em todos esses casos ocorre humanização e enriquecimento, da personalidade e do grupo, por meio de conhecimento oriundo da expressão submetida a uma ordem redentora da confusão.

Entendo aqui por humanização (já que tenho falado tanto nela) o processo que confirma no homem aqueles traços que reputamos essenciais, como o exercício da reflexão, a aquisição do saber, a boa disposição para com o próximo, o afinamento das emoções, a capacidade de penetrar nos problemas da vida, o senso da beleza, a percepção da complexidade do mundo e dos seres, o cultivo do humor. A literatura desenvolve em nós a quota de humanidade na medida em que nos torna mais compreensivos e abertos para a natureza, a sociedade, o semelhante.
}

Compreendida a importância da relação entre a obra literária e a história da literatura, o professor não pode perder de vista o poder humanizador de uma obra literária, a relevância do ensino da recepção estético-literária; ou seja, não pode, durante o ensino de literatura, deixar prevalecer o conhecimento histórico em detrimento da riqueza da vivência estética do aluno. A intrínseca relação entre a obra literária e os agentes do discurso, isto é, a sua historicidade, e o ensino da recepção estético-literária voltado para a humanização do educando devem ser os objetivos primordiais do ensino de literatura.

Segundo Duarte (2012), a recepção estético-literária é a atividade mental de apropriação, pelos indivíduos, de obras produzidas no âmbito da arte e da literatura. Com base nos estudos de Duarte, podemos dizer que o professor deve, no ensino de literatura, exercer uma interferência deliberada e sistematicamente direcionada a fim de fazer com que a apropriação desses bens culturais - no caso, as obras literárias - exerça uma influência positiva sobre o desenvolvimento do indivíduo. Para Duarte, o fato de a apropriação reproduzir a essência da atividade sintetizada no objeto cultural aponta a direção do ensino 


\section{Revista HIIST'TEIDBR On-line}

Artigo

doi: $10.20396 /$ rho.v17i3.8645880

da recepção estético-literária, o qual deve ter como objetivo mover o aluno em um processo que reviva toda a riqueza da atividade presente na obra literária.

É importante aqui enfatizarmos que, conforme atesta Duarte (2012), o ensino não substitui a leitura de um romance, conto, peça de teatro ou poema, mas prepara a recepção da obra literária, orienta essa recepção, oferece-lhe todo o suporte necessário e dialoga criticamente consigo. Para o autor, o propósito do ensino não deve ser o de simplificar o percurso da recepção, mas sim o de formar no aluno as atitudes e ações que colocam o processo da recepção à altura da riqueza contida na obra literária. Nesse caso, pressupomos "[...] que o professor tenha um grande domínio dos vários níveis e dimensões da riqueza da obra, bem como de conhecimentos psicológicos e pedagógicos que lhe permitam prever os efeitos que a obra poderá produzir nos alunos". (DUARTE, 2012, p. 45).

Dessa forma, defendemos um ensino de literatura que, com a mediação de determinados conhecimentos transmitidos pelo docente, proporcione o encontro do aluno com grandes personagens que experimentam um crescimento pessoal e psicológico. Tais personagens, à medida que elevam elementos pessoais e acidentais do próprio destino a certo nível de universalidade, vivem perante os leitores os problemas de seu tempo como individualmente seus e, assim, dotados de virtudes, possibilitam ao educando absorver tais virtudes; desenvolver comportamentos éticos, refinar sua sensibilidade e linguagem e reconhecer-se como ser humano.

O professor, ao proporcionar o ensino da história da Literatura Portuguesa e Brasileira, ao sistematizar esse conhecimento, ao estabelecer com os alunos uma relação entre as características de certa arte literária e seu contexto histórico, ao selecionar a leitura de obras clássicas e adequadas ao nível de desenvolvimento intelectual do educando, estará direcionando, de modo instrutivo, a apropriação de uma obra literária pelo aluno para que o mundo refigurado por esse bem cultural sirva de orientação para a vivência estética receptiva do aluno, instigue-o a compreender-se na totalidade do mundo, a subjugar seu modo habitual de contemplar a realidade, imponha-lhe, pelo efeito catártico, uma nova concepção de mundo, a qual lhe fortalecerá a consciência de si e a sua responsabilidade em relação aos problemas da esfera pública.

É importante esclarecermos aqui que, com base nos pressupostos da pedagogia histórico-crítica, defendemos, para o ensino de literatura, a seleção de obras literárias clássicas, ou seja, aquelas capazes de provocar o efeito catártico no aluno, isto é, capazes de mover a sua subjetividade individual rumo às formas mais ricas de subjetividade já desenvolvidas pelo gênero humano. Noutras palavras, apresentar ao educando situações nas quais decisivas experiências humanas despontam intensificadas e configuradas de modo que consigam impulsionar a sua subjetividade para além da cotidianidade, isto é, a um caminho que desembocará tanto no núcleo da sua própria personalidade como no da realidade social.

A pedagogia histórico-crítica tem sua proposta pedagógica compromissada com a transformação da sociedade, defende a transmissão do conhecimento que possibilita a emancipação humana, que produz a humanização do indivíduo, enfim, que proporciona ao educando a catarse, uma nova visão de realidade. E, dessa forma, podemos afirmar que o ensino de literatura abordado aqui toma como base os propósitos da pedagogia históricocrítica e pretende contribuir para sua edificação, pois, assim como ela, busca socializar os conhecimentos clássicos e, consequentemente, a literatura clássica, como forma de produzir 


\section{Revista HIIST'TEIDBR On-line}

nos indivíduos "a humanidade que é produzida histórica e coletivamente pelo conjunto dos homens" (SAVIANI, 2000, p. 17), busca efetivar uma influência significativa tanto na transformação da sociedade quanto na vida do indivíduo, procura levar o aluno a conhecer a si mesmo como um ser social inserido na história do gênero humano, como um ser que, tendo seus sentimentos cada vez mais refinados e sua visão de mundo cada vez mais apurada, humaniza-se, torna-se homem inteiramente, enfim, torna-se indivíduo para-si.

Perante o atual contexto educacional - sintonizado com o processo de mundialização do capitalismo e, logo, com o projeto político e econômico neoliberal e com o universo ideológico pós-moderno -, o processo de ensino desvaloriza a transmissão do saber objetivo, dilui o papel da escola em transmitir esse saber e proporcionar o acesso à verdade ao educando. Frente a isso se faz necessário lutar, entre tantas outras formas de emancipação humana, por um ensino de Literatura que dê vazão à verdade, possibilite ao leitor o reconhecimento de seu pertencimento ao gênero humano, vise à formação plena do indivíduo, objetive à sua humanização pondo-o em contato com bens culturais que acarretem o pensar, proporcionem perspectivas acerca do mundo e do homem perante a condição humana em meio aos fatores sociais que bloqueiam as possibilidades de desenvolvimento humano.

\section{CONSIDERAÇÕES FINAIS}

Nossa reflexão aqui desenvolvida considerou como ponto de partida a tese segundo a qual há um processo de decadência ideológica na sociedade capitalista que se estende desde a crise espiritual da burguesia e a sua degeneração como classe revolucionária após 1848 até hoje, momento de ápice da difusão do pensamento pós-moderno, a expressão do plano teórico do processo de mundialização do capitalismo.

Analisamos a influêcnia da decadência ideológica e, portanto, do ideário pósmoderno no pensamento pedagógico e educacional e concluímos que a emergência e a difusão da pedagogia escolanovista e todas as suas variantes, ao longo do século XX, são reflexos, no campo educacional, da decadência ideológica do pensamento burguês.

Prosseguimos refletindo como a produção intelectual do período da decadência e, agora, influenciada pela ideologia do pensamento pós-moderno, interfere na educação escolar e, consequentemente no ensino de Língua Portuguesa e de Literatura.

Argumentamos que as atuais concepções de ensino de Literatura são pautadas nos princípios do pensamento pós-moderno, cuja origem, como já dissemos, deve ser averiguada nas primeiras manifestações do processo de decadência ideológica da burguesia, no século XVIII.

Com base nos pressupostos da pedagogia histórico, concluimos que as propostas de ensino que preconizam a não socialização do saber objetivo e, portanto, do conhecimento clássico, não consideram o quanto tal ensino pode contribuir para o desenvolvimento humano.

Dessa forma, concluímos que o atual ensino de Língua Portuguesa, pautado pelo lema "Aprender a aprender", reflete os instrumentos ideológicos da classe dominante cujo 
propósito é esvaziar a educação escolar destinada à maioria da população e está sintonizado com o universo ideológico pós-moderno, originário da referida decadência ideológica.

\section{REFERÊNCIAS}

ABAURRE, M. L.; PONTARA, M. Fundamentação teórico-metodológica. In:

Literatura: tempos, leitores e leituras. 2. ed. São Paulo, Moderna, 2010.

BRASIL. Lei de Diretrizes e Bases da Educação. São Paulo: Fapesp, 1996.

BRASIL. Ministério da Educação e Cultura (MEC). Parâmetros Curriculares Nacionais + Ensino Médio: orientações educacionais complementares aos PCN. Brasília: MEC/ Semtec, 2002.

BRASIL. Parâmetros Curriculares Nacionais - Ensino Médio: linguagens, códigos e suas tecnologias. Brasília: MEC/Semtec, 1999.

CANDIDO, A. Direitos humanos e literatura. In: FESTER, A. C. RIBEIRO. Direitos humanos e... . São Paulo, Brasiliense, 1989.

CANDIDO, A. Literatura e sociedade. 8. ed. São Paulo: T. A. Queiroz, 2000.

CEREJA, W. R. Ensino de literatura: uma proposta dialógica para o trabalho com literatura. São Paulo: Atual, 2005.

CHAUÍ, M. Vocação política e vocação científica da universidade. Educação Brasileira, Brasília, MEC/CRUB, v. 15, n. 31, 1993.

COTRIM, L. A arma da crítica: política e emancipação humana na Nova Gazeta Renana. In: MARX, K. Nova Gazeta Renana: artigos de Karl Marx. Apresentação e tradução: Lívia Cotrim. São Paulo: EDUC, 2010.

COUTINHO, C. N. Literatura e humanismo. Rio de Janeiro: Paz e Terra, 1967.

COUTINHO, C. N. O estruturalismo e a miséria da razão. 2. ed. São Paulo: Expressão Popular, 2010.

COUTINHO, C. N. O estruturalismo e a miséria da razão. Rio de Janeiro: Paz e Terra, 1972.

DERISSO, J. L. Construtivismo, pós-modernidade e decadência ideológica. In: DUARTE, N.; MARTINS, L. M. (Org.). Formação de professores: limites contemporâneos e alternativas necessárias. São Paulo: Cultura Acadêmica, 2010.

DUARTE, N. A rendição pós-moderna à individualidade alienada e a perspectiva marxista da individualidade livre e universal. In: (Org.). Crítica ao fetichismo da individualidade. Campinas: Autores Associados, 2004. 


\section{Revista HIIST'NDBR On-lime}

DUARTE, N. Lukács e Saviani: a ontologia do ser social e a pedagogia histórico- crítica. In: HISTEDBR - VIII Seminário Nacional de Estudos e Pesquisas "História, Sociedade e Educação", 2009, Campinas. Caderno de resumos. Campinas: UNICAMP, 2009. p. 230.

DUARTE, N. Luta de classes, educação e revolução. In: SAVIANI, D.; DUARTE, N. (Org.). Pedagogia histórico-crítica e luta de classes na educação escolar. Campinas: Autores Associados, 2012.

DUARTE, N. Vigotski e o “Aprender a Aprender": críticas às apropriações neoliberais e pós-modernas da teoria vigotskiana. Campinas: Autores Associados, 2006.

FREDERICO, C. Lukács e a defesa do realismo. Revista Cerrados, n. 39, Brasília, v. 24, 2015. p. 108-117.

FREDERICO, C. Marx, Lukács: a arte na perspectiva ontológica. Natal: Editora UFRN, 2005.

HOBSBAWM, E. A era do capital. 21. ed. Rio de Janeiro: Paz e Terra, 2015.

HOBSBAWN, E. A era das revoluções. 2. ed. Rio de Janeiro: Paz e Terra, 1979.

LUKÁCS, G. Arte e sociedade: escritos estéticos 1932-1967. 2. ed. Rio de janeiro: Editora UFRJ, 2011a.

LUKÁCS, G. Correspondência entre Anna Seghers e Georg Lukács. In:

Problemas del realismo. México: Fondo de Cultura Económica, 1966a.

LUKÁCS, G. EI asalto a la razón: la trayectoria del irracionalismo desde Schelling hasta Hitler. Buenos Aires: Fondo de Cultura Económica, 1959.

LUKÁCS, G. Estética: la peculiaridad de lo estético. Barcelona: Grijalbo, 1966b. v. 2.

LUKÁCS, G. Introdução a uma estética marxista: sobre a particularidade como categoria estética. Rio de Janeiro: Civilização Brasileira, 1970.

LUKÁCS, G. Marxismo e teoria da literatura. 2 ed. São Paulo: Expressão Popular, 2010.

LUKÁCS, G. O Romance Histórico. São Paulo: Boitempo, 2011b.

LUKÁCS, G. Realismo crítico hoje. Brasília: Coordenada, 1969.

MARX, K. As lutas de classes na França. São Paulo: Global, 1986.

MARX, K. Nova Gazeta Renana. São Paulo: EDUC, 2010.

PAULO NETTO, J. Posfácio. In: COUTINHO, C. N. O estruturalismo e a miséria da razão. 2. ed. São Paulo: Expressão Popular, 2010. 


\section{Revista HIISTEXIDIR On-line}

SAVIANI, D.; DUARTE, N. Pedagogia histórico-crítica e a luta de classes na educação escolar. Campinas: Autores Associados, 2012.

SAVIANI, D. Educação: do senso comum à consciência filosófica. São Paulo: Cortez/Autores Associados, 1986.

SAVIANI, D. Escola e democracia. Campinas: Autores Associados, 2008a.

SAVIANI, D. Pedagogia Histórico-Crítica: primeiras aproximações. 7. ed. Campinas: Autores Associados, 2000.

SAVIANI, D. Pedagogia Histórico-Crítica: primeiras aproximações. 8. ed. Campinas: Autores Associados, 2008b.

TROTSKY, L. Literatura e revolução. Rio de Janeiro: Jorge Zahar, 2007.

Notas

${ }^{1}$ Possui graduação em Letras e em Pedagogia pela Universidade Estadual Paulista Júlio de Mesquita Filho e mestrado em Educação Escolar pela mesma instituição. No momento, cursa Doutorado no Programa de PósGraduação em Educação Escolar, sob orientação do Prof. Dr. Newton Duarte, e é integrante do grupo de pesquisa "Estudos Marxistas em Educação".

UNESP - Universidade Estadual Paulista. Faculdade de Ciências e Letras. Araraquara - SP - Brasil.

14800-001 - lalaquachio@yahoo.com.br

2 Segundo Duarte (2006), o "aprender a aprender", compreendido como emblema dos ideais pedagógicos escolanovistas, manteve-se presente e forte no ideário pedagógico brasileiro independentemente da existência ou não de menções explícitas ao movimento escolanovista e aos autores que foram as principais referências desse movimento.

${ }^{3}$ Segundo Saviani (2005, p. 146), na síncrese a visão de tudo é confusa e caótica, não se tem clareza dos elementos que constituem a realidade e já na síntese há visão do todo com a consciência e a clareza das partes que o constituem.

Submetido em: 20/09/2017

Aprovado em: 11/10/2017 